\title{
Correction: Taxonomic diversity of fungi deposited from the atmosphere
}

\author{
Cheolwoon $\mathrm{Woo}^{1} \cdot$ Choa $\mathrm{An}^{1} \cdot$ Siyu $\mathrm{Xu}^{1} \cdot$ Seung-Muk $\mathrm{Yi}^{1,2} \cdot$ Naomichi Yamamoto $\mathbb{(}^{1,2}$
}

Published online: 21 October 2019

(c) The Author(s) 2019. This article is published with open access

\section{Correction to: The ISME Journal}

$$
\text { https://doi.org/10.1038/s41396-018-0160-7 }
$$

Since publication of our article, the authors have identified an error in Eq. (1). The correct equation is

$$
V_{d}=\frac{\sum_{j=1}^{6} F_{j}}{\sum_{j=1}^{6} \sum_{i=1}^{5} N_{j, i}}
$$

All the reported results are calculated correctly by this equation. Therefore, there is no change in our reported values. The authors would like to apologize for any inconvenience caused by this error.
Open Access This article is licensed under a Creative Commons Attribution 4.0 International License, which permits use, sharing, adaptation, distribution and reproduction in any medium or format, as long as you give appropriate credit to the original author(s) and the source, provide a link to the Creative Commons license, and indicate if changes were made. The images or other third party material in this article are included in the article's Creative Commons license, unless indicated otherwise in a credit line to the material. If material is not included in the article's Creative Commons license and your intended use is not permitted by statutory regulation or exceeds the permitted use, you will need to obtain permission directly from the copyright holder. To view a copy of this license, visit http://creativecommons. org/licenses/by/4.0/.

These authors contributed equally: Cheolwoon Woo, Choa An

The original article can be found online at https://doi.org/10.1038/ s41396-018-0160-7.

Naomichi Yamamoto

nyamamoto@snu.ac.kr

1 Department of Environmental Health Sciences, Graduate School of Public Health, Seoul National University, Seoul 08826, Republic of Korea

2 Institute of Health and Environment, Seoul National University, Seoul 08826, Republic of Korea 